that our account of the decadal variability in tropical North Atlantic $\mathrm{SST}^{26}$ is an alternative to the hypothesis that this region is under the control of processes local to the tropical Atlantic $c^{27,28}$.

By exploiting the memory inherent in the decadal fluctuations, our results suggest it may be possible to predict a significant fraction of the low-frequency variability in North Atlantic SST and sea-level pressure several years in advance. Although further work will be needed before a serious attempt at forecasting can be made, particularly investigation with models of the mechanisms we have discussed, we consider briefly the outlook for the decadal fluctuations. We have examined the most recent evolution of North Atlantic SST in the NOAA NCEP analyses ${ }^{29}$ and of North Atlantic sea-level pressure in the NCEP reanalyses ${ }^{30}$. SST in the stormformation region reached a maximum in the late 1980s and has since been falling. In line with our expectations of the atmospheric response, sea-level pressure in the region marked $\mathrm{C}$ in Fig. $2 \mathrm{~b}$ peaked at the end of the 1980s and has since been falling, whereas sea-level pressure in the region marked $B$ reached a minimum at the same time and has since been rising. Also consistent with our understanding, SST in the mid-Atlantic at $\sim 50^{\circ} \mathrm{N}$ reached a minimum in the late 1980 s and has since been rising. Similar, if somewhat less clear, behaviour is seen in tropical North Atlantic SST. Based on the apparent period of 12-14 years, and to the extent that other influences (for example, El Niño and multidecadal fluctuations) allow, we expect all these trends to continue into the next century before reversing.

Received 12 May; accepted 17 June 1997.

1. Deser, C. \& Blackmon, M. L. Surface climate variations over the North Atlantic ocean during winter: 1900-1989. J. Clim. 6, 1743-1753 (1993).

. Kushnir, Y. Interdecadal variations in North Atlantic sea surface temperature and associated atmospheric conditions. J. Clim. 7, 141-157 (1994).

3. Battisti, D. S., Bhatt, U. S. \& Alexander, M. A. A modelling study of the interannual variability in the wintertime North Atlantic ocean. J. Clim. 8, 3067-3083 (1995).

4. Hansen, D. V. \& Bezdek, H. F. On the nature of decadal anomalies in North Atlantic sea surface temperature. J. Geophys. Res. 101, 8749-8758 (1996).

5. Delworth, T. L. North-atlantic interannual variability in a coupled ocean-atmosphere model. J. Clim. 9, 2356-2375 (1996)

6. Molinari, R. L., Mayer, D., Festa, F. \& Bezdek, H. Multiyear variability in the near surface temperature structure of the midlatitude western North Atlantic ocean. J. Geophys. Res. 102, 3267-3278 (1997).

Grötzner, A., Latif, M. \& Barnett, T. P. A decadal climate cycle in the North Atlantic ocean as simulated by the ECHO Coupled GCM. J. Clim. (submitted).

8. Palmer, T. N. \& Sun, Z. A modeling and observational study of the relationship between sea surface temperature in the Northwest Atlantic and the atmospheric general circulation. Q. J. R. Meteorol. Soc 111, 947-975 (1985).

9. Peng, S., Mysak, L. A., Ritchie, H., Derome, J. \& Dugas, B. The differences between early and midwinter atmospheric responses to sea surface temperature anomalies in the Northwest Atlantic. J. Clim. 8, 137-157 (1995).

10. Kushnir, Y. \& Held, I. M. Equilibrium atmospheric response to North Atlantic SST anomalies. J. Clim. 9, 1208-1220 (1996)

11. Griffies, S. M. \& Bryan, K. Predictability of north atlantic multidecadal climate variability. Science 275, 181-184 (1997)

12. Mann, M. E. \& Park, J. Joint spatiotemporal modes of surface temperature and sea level pressure variabiity in the Northern Hemisphere during the last century. J. Clim. 9, 2137-2161 (1996).

13. Houghton, R. W. Subsurface quasi-decadal fluctuations in the North Atlantic. J. Clim. 9, 1361-1373 (1996).

14. Bjerknes, J. Atlantic air-sea interaction. Adv. Geophys. 10, 1-82 (1964).

15. daSilva, A., Young, A. C. \& Levitus, S. NOAA SMD94 (Tech. Rep. 6, US Dept of Commerce, NOAA, NESDIS, Washington DC, 1994).

16. Schmitz, W. J. \& McCartney, M. S. On the North Atlantic circulation. Rev. Geophys. 31, 29-49 (1993).

17. Stommel, H. The Gulf Stream (Univ. California Press, Berkeley, 1965).

18. Levitus, S., Antonov, J. I. \& Boyer, T. P. Interannual variability of temperature at a depth of 125 metres in the North Atlantic ocean. Science 266, 96-99 (1994).

19. Reverdin, G., Cayan, D. \& Kushnir, Y. Decadal variability of hydrography in the upper North Atlantic 1948-1990. J. Geophys. Res. 102, 8505-8531 (1997)

20. Dickson, R. R., Meincke, J., Malmberg, S.-A. \& Lee, A. J. The "Great Salinity Anomaly" in the northern North Atlantic 1968-1982. Prog. Oceanogr. 20, 103-151 (1988).

21. Frankignoul, C. Sea surface temperature anomalies, planetary waves, and air-sea feedback in the middle latitudes. Rev. Geophys. 23, 357-390 (1985).

22. Roebber, P. J. Statistical analysis and updated climatology of explosive cyclones. Mon. Weath. Rev. 112, $1577-1589(1984)$

23. Hoskins, B. J. in Large Scale Dynamical Processes in the Atmosphere (eds Hoskins, B. J. \& Pearce, R. P.) 169-199 (Academic, London, 1983).

24. Latif, M. \& Barnett, T. P. Causes of decadal climate variability over the North Pacific/North American sector. Science 266, 634-637 (1994).

25. White, W. B., Lean, J., Cayan, D. R. \& Dettinger, M. D. Response of global upper ocean temperature to changing solar irradiance. J. Geophys. Res. 102, 3255-3266 (1997).

26. Allen, M. R. \& Smith, L. A. Investigating the origins and significance of low-frequency modes of climate variability. Geophys. Res. Lett. 21, 883-886 (1994).

27. Mehta, V. M. \& Delworth, T. Decadal variability of the tropical Atlantic ocean surface temperature in shipboard measurements and in a global ocean-atmosphere model. J. Clim. 8, 172-190 (1995).

28. Chang, P., Ji, L. \& Li, H. A decadal climate variation in the tropical Atlantic ocean from thermodynamic air-sea interactions. Nature 385, 516-518 (1997).
29. Reynolds, R. W. \& Smith, T. M. Improved sea surface temperature analyses using optimum interpolation. J. Clim. 7, 929-948 (1994).

30. Kalnay, E. et al. The NCEP/NCAR 40-year reanalysis project. Bull. Am. Meteorol. Soc. 77, 437-471 (1996).

31. Saravanan, R. \& McWilliams, J. C. Advective ocean-atmosphere interaction: an analytical stochastic model with implications for decadal variability. J. Clim. (in the press).

Acknowledgements. We thank T. Haine for comments on earlier drafts, and W. Schmitz and M. McCartney for permission to reproduce Fig. la. R.T.S. was supported by the UK NERC Universities Global Atmospheric Modelling Programme, M.R.A. was supported by the NERC/RAL Ocean Dynamics Service Level Agreement.

Correspondence should be addressed to R.T.S. (e-mail: atmrts@atm.ox.ac.uk).

\section{Orbitally paced climate oscillations across the Oligocene/Miocene boundary}

\section{James C. Zachos ${ }^{\star}$, Benjamin P. Flower $\nmid \ddagger$ \& Hilary Paul ${ }^{\star}$}

* Earth Science Department, $†$ Institute of Marine Sciences,

University of California, Santa Cruz, California 95064, USA

The late Oligocene and early Miocene periods, some 21 to 27 million years ago, have generally been viewed as times of moderate global warmth and ice-free conditions. Yet several lines of evidence suggest that this interval was punctuated by at least one, and possibly several, episodes of high-latitude cooling and continental glaciation ${ }^{1-3}$. Here, we present stable-isotope and per cent coarse-fraction data from an equatorial, western Atlantic deepsea-sediment core that provide high-resolution records of the climate variability across the Oligocene/Miocene transition (22.5-25.7 million years ago). A strong 40-kyr periodicity in the oxygen isotope record is consistent with a high-latitude orbital (obliquity) control on ice-volume and temperature. Orbital influences are also apparent at precession and eccentricity frequencies, including a series of $\sim 400-\mathrm{kyr}$ oscillations that culminate in distinct maxima at the Oligocene/Miocene boundary, about 23.7 million years ago. Covariance between the carbon and oxygen isotope records suggests that the oceanic carbon cycle may have contributed to global cooling during the $\sim 400$-kyr cycles, particularly at the Oligocene/Miocene boundary.

The Oligocene/Miocene boundary represents a significant climate transition in Cenozoic Earth history; ocean temperatures were slowly increasing and continental ice-volume was apparently decreasing from the large accumulations of the middle-late Oligocene $^{2-4}$. Oxygen isotope records indicate that this trend may have been interrupted by a series of brief glaciations that began in the earliest Miocene and continued up to the time of significant middle Miocene cooling ${ }^{2}$. The first and largest of these events, Mi-1, occurred at the Oligocene/Miocene boundary.

As with most other pre-Pliocene intervals, previous isotope records that span the Oligocene/Miocene boundary lack the sampling density needed to resolve palaeoenvironmental changes occurring on timescales of $<10^{5}$ years. Attempts to construct higher resolution records have been hampered either by the lack of continuous, undisturbed sedimentary sections, or by diagenetic overprinting. These deficiencies were recently resolved with the successful recovery of an expanded and hiatus-free section of upper Oligocene and lower Miocene nannofossil chalk in Hole 929A, on Ceara rise in the western equatorial Atlantic Ocean (ref. 5) $(4360 \mathrm{~m}$ water depth). This section is characterized by prominent decimetrescale oscillations in sediment colour and magnetic susceptibility with periods similar to those associated with orbital forcing ${ }^{6}$.

\$Present address: Department of Marine Science, University of South Florida, St Petersburg, Florida 33701, USA. 
Using samples from Hole 929A, we assembled high-resolution (10-cm sampling) isotope and per cent coarse-fraction time series for the Oligocene/Miocene boundary (22.5-25.7 Myr ago). Initially, samples were collected from four cores (929A 34X-37X) spanning a 40 - $\mathrm{m}$ interval across the boundary ${ }^{7}$. We subsequently increased the length of the record to $60 \mathrm{~m}$ by adding samples from two additional

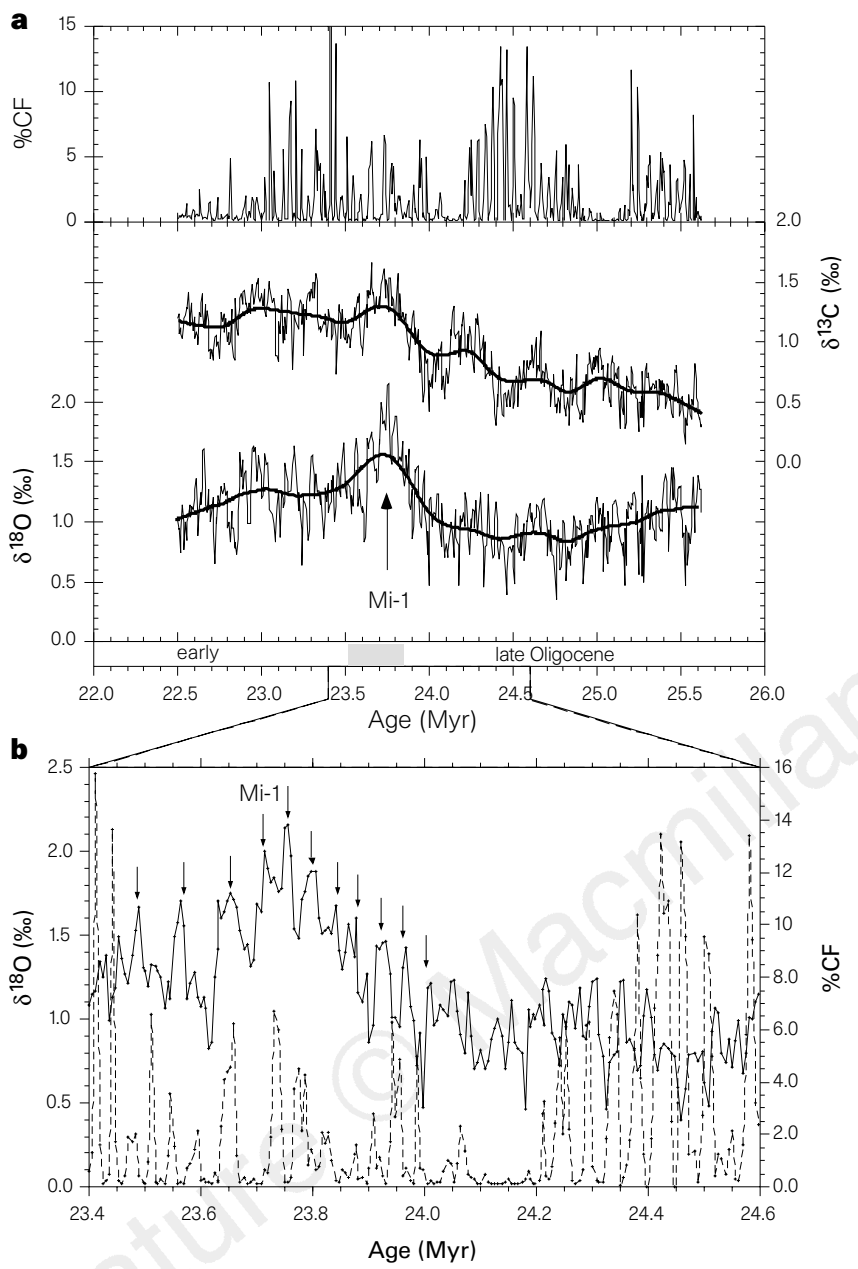

Figure 1 a, Benthic foraminifer stable-isotope and \% coarse fraction (\%CF) records for Hole 929A plotted versus age. Each sample was freeze-dried, weighed, washed and wet sieved over a $63-\mu \mathrm{m}$ screen. The $>63 \mu \mathrm{m}$ fraction was dried and weighed to calculate \%CF. From five to ten specimens of benthic foraminifer taxa, Cibidoides mundulus, were then picked from the $>150-\mu \mathrm{m}$ fraction of each sample and analysed for carbon and oxygen isotopic composition. Stable-isotope analyses were carried out in the Stable Isotope Laboratory at the University of California, Santa Cruz using a common acid-bath device coupled to either a Fisons PRISM or an OPTIMA mass spectrometer ${ }^{12}$. All values are reported in the per mil (\%) notation relative to Pee Dee Belemnite standard. External precision based on duplicates and triplicates is better than \pm 0.09 for both and $\mathrm{C}$ and $\mathrm{O}$ isotopes. The $\% \mathrm{CF}$ represents the mass of the $>63-\mu \mathrm{m}$ size fraction relative to the total mass of each sample. The heavy lines in the stable-isotope plots represent the curve fits (locally weighted (15\%) means) used for detrending. The age model is based on sedimentation rates inferred from the wavelength of the 40-kyr cycle in magnetic susceptibility ${ }^{6}$. This age model proved to be superior to one based exclusively on biostratigraphic datums which, because of dissolution and low abundances of planktonic microfossils at this site, tended to be less reliable. Nevertheless, the differences between the two age models are relatively small (see Supplementary Information). b. Expanded view of the oxygen-isotope (solid line; left-hand ordinate) and \%CF (dashed line;righthand ordinate) records for the period 23.4-24.6 Myr ago. The arrows denote individual "glacial maxima" associated with the Mi-1 event. cores (929A 33X-38X) to create time series nearly 3.2 Myr long across the Oligocene/Miocene boundary. Core recovery was 100\% over this interval. Site-to-site comparisons of magnetic susceptibility and colour reflectance data suggest inter-core gaps of $<40 \mathrm{~cm}$ $(\sim 20 \mathrm{kyr})^{5}$. The stable-isotope record, plotted in Fig. 1 along with per cent coarse fraction (\% CF), is based on the carbon and oxygen isotope ratios of the benthic foraminifer, Cibicidoides mundulus. The age model is based on sedimentation rates derived from the Hole 929A biostratigraphy ${ }^{5}$ and the wavelength of the 40-kyr cycle in the magnetic susceptibility record ${ }^{6}$ (Table 1). Ages are cumulative, starting from an assigned age of $22.5 \mathrm{Myr}$ for the uppermost

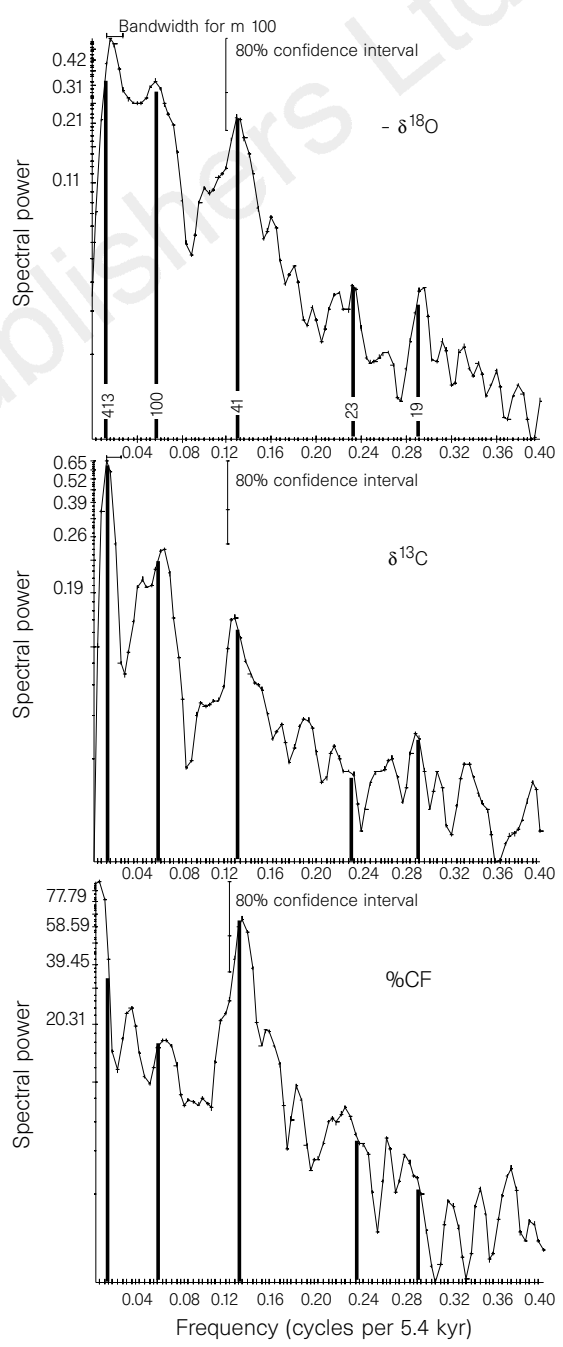

Figure 2 Power spectra (variance versus frequency) of three variables, the benthic $\delta^{18} \mathrm{O}$ and $\delta^{13} \mathrm{C}$, and \%CF values. The left-hand ordinate shows the spectral power of each record. Bandwidth (0.0133) and confidence intervals (80\%) are shown. The time-series analysis was carried out using a numerical approach based on the Blackman-Tukey method (SPECTX; Oregon State Univ.). Following SPECMAP convention, the oxygen isotope record was multiplied by -1 so that interglacials (less ice and warmer temperatures) are represented by higher values. After converting to age, the data set was resampled at an equal time interval of $5.4 \mathrm{kyr}(n=578)$. The number of lags $(m)$ was set to 100 . To resolve the lower-frequency components of the oxygen and carbon isotope time series, locally weighted means (Fig. 1a) were fitted to the records and subtracted to remove the longer-term trends from each time series. Residual long-term trends were then removed using a linear detrend. This pre-processing substantially improved the degree to which variance at the low-frequency ( 400 and $100 \mathrm{kyr}$ ) end of the spectrum could be resolved. The vertical bars show the frequencies of the primary orbital periods. 
level (core 929A-33X, $10 \mathrm{~cm} ; 301.10 \mathrm{~m}$ below sea floor) of the sampled section. This age is based on an interpolation of two biostratigraphic age datums calibrated against the most recent Geomagnetic Polarity Time Scale (GPTS) ${ }^{8}$.

The oxygen-isotope time series shows changes on several different scales, including pervasive high- and low-frequency $\left(\sim 10^{4}-10^{5} \mathrm{yr}\right)$ oscillations and a brief positive $\delta^{18} \mathrm{O}$ excursion of $1.2 \%$ just above the Oligocene/Miocene boundary (Fig. 1a). The high-frequency oscillations have amplitudes of between 0.5 and $0.6 \%$; the lowerfrequency oscillations have slightly larger amplitudes. The 1.2\%o excursion initiated 24.0 Myr ago and peaked at 23.7 Myr. The magnitude and timing suggest it is equivalent to the Mi-1 event. In detail, it consisted of a series of higher-frequency cycles of varying amplitude superimposed on a longer-term increase (Fig. 1b). The carbon isotope record also shows variability on several scales, including high- and low-frequency oscillations, and a long-term rise. The high-frequency cycles are of small amplitude, generally $<0.4 \%$. The lower-frequency cycles are of significantly larger amplitude, in excess of $0.8 \%$, and appear to covary with oxygen isotopes over most of the record. The long term rise began $\sim 25.0 \mathrm{Myr}$ ago and peaked at $23.65 \mathrm{Myr}$ with mean $\delta^{13} \mathrm{C}$ values increasing by $>0.7 \%$.

The coarse fraction $(>63-\mu \mathrm{m})$ of these sediments consists largely of planktonic foraminifer tests. The \%CF record is dominated by high-frequency variability $\left(\sim 10^{4} \mathrm{yr}\right)$ with values varying between 0.1 and $12 \%$. A low-frequency pattern is present as well; there are three intervals, each 100-200 kyr long, with low mean concentrations and values of \%CF rarely exceeding $1 \%$. These three intervals are centred at roughly 22.8, 24.1 and 25.1 Myr ago.

To identify the main periods of variance in the isotope and \%CF records, as well as internal phase relationships (coherency) between variables, spectral and cross-spectral analyses were carried out using a program based on the Blackman-Tukey method ${ }^{9}$ (for details see legends of Figs 2 and 3). High concentrations of variance in the $\delta^{18} \mathrm{O}$

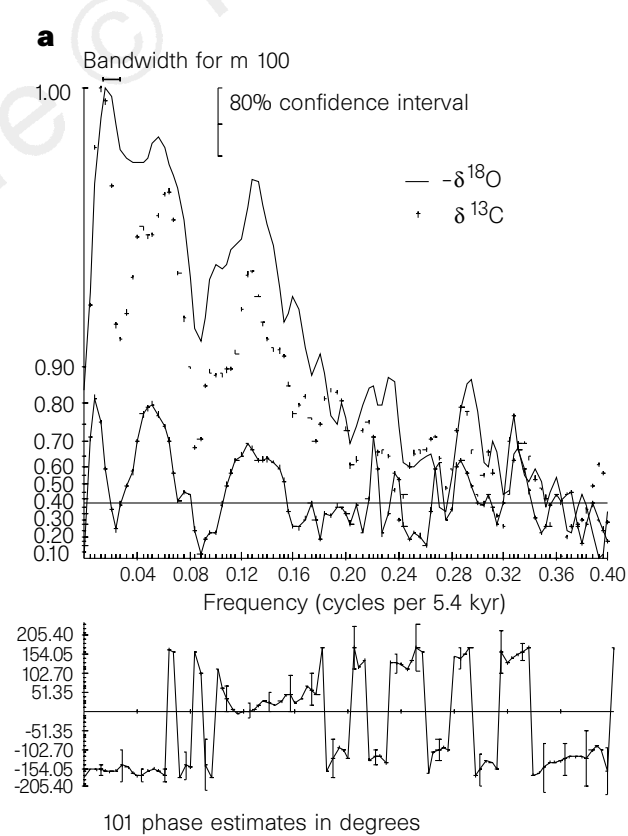

Figure 3 Top panels, coherence spectra of the $\delta^{13} \mathrm{C}$ (panel a) and \%CF (panel b) time series relative to $\delta^{18} \mathrm{O}$ (solid lines). Following SPECMAP convention, all $\delta^{18} \mathrm{O}$ values were multiplied by -1 so that phase relationships are relative to glacial minima rather than maxima. The isotope time series were detrended by subtracting a locally weighted mean, and then resampled at a constant 5.4-kyr time interval. Variance density and coherency (solid line with plus signs) were spectrum were identified at frequency components that correspond to the Milankovitch periods of $19,23,40,100$ and $\sim 413 \mathrm{kyr}(0.284$, $0.235,0.130,0.054$ and 0.013 cycles per $5.4 \mathrm{kyr}$; Fig. 2). The $\delta^{13} \mathrm{C}$ spectra shows concentration of variance at the 19-, 41-, 100- and $\sim 413$-kyr periods, whereas the \%CF spectra is dominated by the 40 kyr period.

At the $\sim 400$ - and 100 -kyr periods, $-\delta^{18} \mathrm{O}\left(\delta^{18} \mathrm{O}\right.$ is multiplied by -1 following SPECMAP convention) and $\delta^{13} \mathrm{C}$ show a highdegree coherency $\left(k=0.91\right.$ and 0.89 , respectively), with $-\delta^{18} \mathrm{O}$ (glacial minima) nearly $180^{\circ}$ out of phase with $\delta^{13} \mathrm{C}$ (Fig. 3a). These variables are also coherent $(k=0.72)$ and nearly in phase at the 40-kyr period. A high degree of coherency $(k=0.85)$ also occurs between $\% \mathrm{CF}$ and $\delta^{18} \mathrm{O}$ at the $40-\mathrm{kyr}$ period with $-\delta^{18} \mathrm{O}$ lagging $\%$ CF by $40^{\circ}(4.4 \pm 1.7 \mathrm{kyr}$; Fig. $3 \mathrm{~b})$.

The strong response in the oxygen isotope record at the obliquity (40-kyr) period is significant. Because the effects of obliquity on insolation are strongest at high latitudes ${ }^{10}$, oscillations with a $40-\mathrm{kyr}$ period suggest a high-latitude climate control (ice-volume and/or temperature) on $\delta^{18} \mathrm{O}$ across the Oligocene/Miocene boundary. This finding, along with evidence of similar periodicities in earliest Oligocene and early middle Miocene oxygen isotope records ${ }^{11,12}$, as well as in Plio-Pleistocene records, suggests that a strong response to obliquity forcing has been a common feature of the global climate signal for at least the past $34 \mathrm{Myr}$.

These obliquity-paced climate oscillations were closely linked to deep-water circulation patterns and chemistry. At the 40-kyr period, \%CF appears to be tightly coupled to $\delta^{18} \mathrm{O}$ over most of this record (Fig. 3a). Three factors can influence \%CF: surface production, dilution by terrigeneous debris, and dissolution ${ }^{13}$. At Hole 929A, a general association of low \%CF with increased fragmentation and low carbonate concentration (as inferred from magnetic susceptibility and colour reflectance ${ }^{5}$ ) indicates that dissolution was the controlling factor. This coupling of $\delta^{18} \mathrm{O}$ and carbonate dissolution is similar to patterns observed in Quaternary

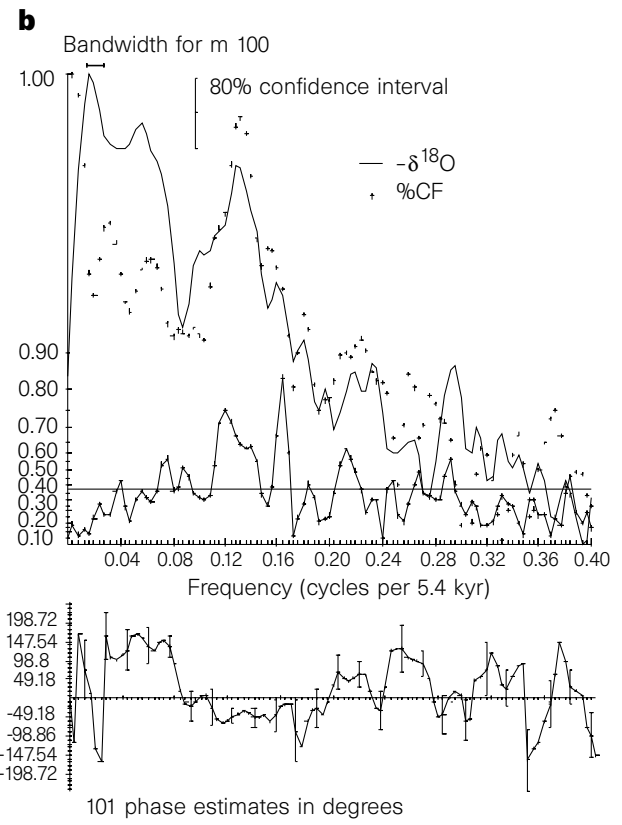

calculated based on 100 lags of the autocovariance function. The coherencies are plotted on a hyperbolic arctangent scale along the $y$-axis so that the confidence intervals for the coherency estimates are a constant length. The horizontal line is the $80 \%$ confidence interval testing the non-zero hypothesis for the estimates. Bottom panels, the phase angles (in degrees) and associated $80 \%$ confidence intervals (vertical lines). 


\begin{tabular}{|c|c|c|c|c|}
\hline Cores & $\begin{array}{c}\text { Depth } \\
\text { (m below sea floor) }\end{array}$ & $\begin{array}{l}\text { Wavelength* } \\
(\mathrm{m})\end{array}$ & $\begin{array}{l}\text { Sed. rate* } \\
\left(\mathrm{m} \mathrm{Myr}^{-1}\right)\end{array}$ & $\begin{array}{l}\text { Age } \\
\text { (Myr) }\end{array}$ \\
\hline 929A-33-34X & $301.05-320.36$ & 0.683 & 17.1 & $22.500-23.626$ \\
\hline 929A-35-36X & $320.45-339.61$ & 0.659 & 16.5 & $23.630-24.793$ \\
\hline 929A-37-38X & $339.70-356.80$ & 0.826 & 20.7 & $24.797-25.623$ \\
\hline
\end{tabular}

* From ref. 6: 'Wavelength' means wavelength of the primary cycles of magnetic susceptibility, 'sed. rate' means sedimentation rate.

sediments $^{14,15}$ and can be explained by increased flux of more corrosive bottom water into the equatorial Atlantic during glacial periods. The presence of a south-to-north decrease in deep-water $\delta^{13} \mathrm{C}$ during the early Miocene ${ }^{16}$ suggests a Southern Ocean source for this more corrosive water.

The Hole $929 \delta^{18} \mathrm{O}$ record resolves two critical features of the Mi-1 glacial maximum. The first is the structure of the Mi-1 excursion; it actually consisted of a series of higher-frequency (40-, 100-kyr) oscillations superimposed on a long-term increase (Fig. 1b). The direct response at the 100-kyr cycle appears to be slightly stronger just after the Mi-1 event, although further work is needed to resolve the detailed evolution of the climate spectra over this and other intervals. The second important feature is the magnitude of Mi-1; a $1.2 \%$ increase requires an accumulation of continental ice equivalent in volume to the present-day East Antarctic Ice Sheet, or $5-6^{\circ} \mathrm{C}$ cooling of bottom waters, or, more likely, some combination of ice-volume/temperature change. The presence of Upper Oligocene and Lower Miocene glacial marine sediments in the Ross Sea ${ }^{1,17}$, as well as new evidence that links a prominent eustatic lowering ${ }^{18}$ to $\mathrm{Mi}-1^{19}$ suggests that part of the $\delta^{18} \mathrm{O}$ increase was due to ice-sheet expansion.

Perhaps the most intriguing features of the isotope spectra are the high-amplitude $\sim 400$-kyr oscillations, particularly in $\delta^{13} \mathrm{C}$. Variance in climate near this period, as well as at the $100-\mathrm{kyr}$ period, is thought to originate from an asymmetrical response mechanism that preferentially introduces variance from the warmer portions of the eccentricity modulated precession cycle $^{20}$. Although rarely recorded in Pliocene/Pleistocene $\mathrm{e}^{20,21}, \sim 400$-kyr oscillations commonly arise in lower-resolution Oligocene and Miocene benthic foraminiferal $\delta^{13} \mathrm{C}$ time series ${ }^{12,22-24}$. Such a strong expression of this period in the carbon isotope record indicates a nonlinear relation between the carbon cycle and eccentricity forcing. At Hole 929A, $\delta^{18} \mathrm{O}$ and $\delta^{13} \mathrm{C}$ are closely coupled at the $\sim 400$-kyr period (lag $\sim 24 \pm 20 \mathrm{kyr}$ ) as well as at 100 -kyr period, with $\delta^{18} \mathrm{O}$ leading $\delta^{13} \mathrm{C}$. Covariance between oxygen and carbon in early Oligocene and middle Miocene records has previously been attributed to the effects of climate change on ocean/atmosphere circulation, ocean productivity, and organic carbon ${ }^{23-25}$. Investigators speculate that as high-latitude temperatures decrease and ice sheets grow, oceanic and atmospheric circulation intensify, increasing oceanic turnover, productivity and organic-carbon fluxes. In turn, burial rates of organic carbon increase thereby driving mean ocean $\delta^{13} \mathrm{C}$ towards higher values ${ }^{26}$. The process apparently reverses as climate warms and/or nutrient levels are reduced. This coupling may have helped amplify the response at the lower frequencies.

Close coupling of climate (as expressed by $\delta^{18} \mathrm{O}$ ) and the oceanic carbon cycle may also explain the unusual scale of the Mi-1 event. If the low-frequency carbon-isotope cycles reflect periodic changes in the rate of organic-carbon burial as postulated above, it is likely that the atmospheric partial pressure of $\mathrm{CO}_{2}\left(p_{\mathrm{CO}_{2}}\right)$ was oscillating as well, and generating a positive feedback. We speculate that the variations in $p_{\mathrm{CO}_{2}}$ during the Oligocene were within a range where the feedback on the global radiative balance was comparatively small until the earliest Miocene (Mi-1) when $p_{\mathrm{CO}_{2}}$ had dropped below some threshold. The process of reaching this threshold was probably gradual, as suggested by the progressive step by step increase in carbon isotope ratios before $\mathrm{Mi}-1$, a trend which indicates significant oceanic carbon-cycle change during the latest Oligocene.

The Hole 929A isotope times series presented here provide critical new insight into the character of climate variability across the Oligocene/Miocene transition. The persistence of a strong 40kyr period in the $\delta^{18} \mathrm{O}$ record is consistent with the presence of Antarctic ice sheets during this period of moderate global warmth. Documentation of 100- and 400-kyr periods provides strong support for a palaeoceanograhic response to the longer-period Milankovitch cycles. Covariance between $\delta^{13} \mathrm{C}$ and $\delta^{18} \mathrm{O}$ at these eccentricity periods hints at a strong coupling between climate and the ocean carbon cycle. Tuning of the Hole 929 isotope time series to orbital spectra (N. J. Shackleton, personal communication) will ultimately produce a standard reference section that will provide a degree of chronostratigraphic control for the late Oligocene to early Miocene that approaches that of the Quaternary.

Received 10 March; accepted 18 June 1997

1. Leckie, R. M. \& Webb, P. N. Late Oligocene-early Miocene glacial record of the Ross Sea, Antarctica: evidence from DSDP Site 270. Geology 11, 578-582 (1983).

2. Miller, K. G., Wright, J. D. \& Fairbanks, R. G. Unlocking the ice house: Oligocene-Miocene oxygen isotopes, eustacy and margin erosion. J. Geophys. Res. 96, 6829-6848 (1991).

3. Wright, J. D. \& Miller, K. G. Miocene stable isotope stratigraphy, Site 747, Kerguelen Plateau. Proc. ODP Sci. Res. 120, 855-866 (1992).

4. Stott, L. D., Kennett, J. P., Shackleton, N. J. \& Corfield, R. M. The evolution of Antarctic surface waters during the Paleogene, inferences from the stable isotopic composition of planktonic foraminifera. Proc. ODP Sci. Res. 113, 849-864 (1990).

5. Curry, W. B. et al. Init. Rep. ODP A 154, (1995).

6. Weedon, G. P., Shackleton, N. J. \& Pearson, P. N. The Oligocene time scale and cyclostratigraphy on the Ceara Rise, Western Equatorial Atlantic. Proc. ODP Sci. Res. (in the press).

7. Flower, B. P., Zachos, J. C. \& Paul, H. Milankovitch-scale variability recorded near the Oligocene/ Miocene Boundary: Hole 929A. Proc. ODP Sci. Res. (in the press).

8. Berggren, W. A. et al. in Geochronology, Time Scales and Global Stratigraphic Correlation (eds Berggren, W. A., Kent, D. V., Aubry, M.-P. \& Hardenbol, J.) 129-212 (Spec. Publ. 54, Soc. Econ. Paleontol. Mineral., Tulsa, OK, 1995).

9. Jenkins, G. M. \& Watts, D. G. Spectral Analysis and its Applications (Holden-Day, San Francisco, 1968). 10. Berger, A. \& Loutre, M. F. Insolation values for the climate of the last 10 m.y. Quat. Sci. Rev. 10, 297317 (1991).

11. Pisias, N. G., Shackleton, N. J. \& Hall, M. A. Stable isotope and calcium carbonate records from hydraulic piston cored Hole 574A: high-resolution records from the middle Miocene. Init. Repts DSDP 85, 735-748 (1985).

12. Zachos, J. C., Quinn, T. M. \& Salamy, K. Earliest Oligocene climate transition: Constraints from high resolution $\left(10^{4} \mathrm{yr}\right)$ deep-sea foraminiferal $\delta^{18} \mathrm{O}$ and $\delta^{13} \mathrm{C}$ time series. Paleoceanography 11, 251-266 (1996).

13. Wu, G., Herguera, J. C. \& Berger, W. H. Differential dissolution, modification of late Pleistocene oxygen isotope records in the western equatorial Pacific. Paleoceanography 5, 581-594 (1990).

14. Bassinot, F. C. et al. Coarse fraction fluctuations in pelagic carbonate sediments from the tropical Indian Ocean: A 1500-kyr record of carbonate dissolution. Paleoceanography 9, 579-600 (1994).

15. Curry, W. B., Duplessy, J. C., Labeyrie, L. D., Oppo, D. \& Kallel, N. P. Changes in the distribution of $\delta^{13} \mathrm{C}$ of $\Sigma \mathrm{CO}_{2}$ between the last glaciation and the Holocene. Paleoceanography 3, 317-342 (1988).

16. Wright, J. D. \& Miller, K. G. in The Antarctic Paleoenvironment: A Perspective on Global Change (eds Kennett, J. P. \& Warnke, D. A.) 141-165 (Antarctic Res. Ser. 56, Am. Geophys. Un., Washington DC, 1993).

17. Barrett, P. J. (ed.) Antarctic Cenozoic History From CIROS-1 Drill Hole McMurdo Sound. NZ DSIR Bull. 245, 1-251 (1989).

18. Haq, B. U., Hardenbol, J. \& Vail, P. R. Chronology of fluctuating sea levels since the Triassic. Science 235, 1156-1167 (1987)

19. Miller, K. G. et al. Drilling and dating New Jersey Oligocene-Miocene sequences; ice volume, global sea level, and Exxon records. Science 271, 1092-1095 (1996).

20. Clemens, S. C. \& Tiedemann, R. Eccentricity forcing of Pliocene-Early Pleistocene climate revealed in a marine oxygen isotope record. Nature 385, 801-804 (1997).

21. Mix, A. C. et al. Benthic Foraminifer stable isotope record from Site 849, 0-5 Ma: Local and global climate changes. Proc. ODP Sci. Res. 138, 371-412 (1995).

22. Diester-Haass, L. \& Zahn, R. Eocene-Oligocene transition in the Southern Ocean: History of water mass circulation and biological productivity. Geology 24, 163-166 (1996).

23. Woodruff, F. \& Savin, S. M. Mid-Miocene isotope stratigraphy in the deep sea: high-resolution correlations, paleoclimatic cycles, and sediment preservation. Paleoceanography 6, 755-806 (1991).

24. Flower, B. P. \& Kennett, J. P. Middle Miocene deepwater paleoceanography in the southwest Pacific: Relations with east Antarctic ice sheet development. Paleoceanography 10, 1095-1113 (1995).

25. Flower, B. P. \& Kennett, J. P. Middle Miocene ocean/climate transition: High-resolution oxygen and carbon isotopic records from DSDP Site 588A, Southwest Pacific. Paleoceanography 8, 811-843 (1993).

26. Shackleton, N. J. Marine Petroleum Source Rocks (eds Brooks, J. et al.) 423-434 (Spec. Publ. 26, Geol. Soc., London, 1987).

Supplementary Information is available on Nature's World-Wide Web site (http://www.nature.com) or as paper copy from Mary Sheehan at the London editorial office of Nature.

Acknowledgements. We thank S. Clemens, P. DeMenocal, P. Koch, N. Shackleton, J. Revenaugh and Q. Williams for comments and discussion; K. Vencil for technical assistance; and S. D'Hondt, L. Hinnov and K. Miller for reviews that significantly improved the manuscript. Samples for this project were provided by the Ocean Drilling Program. This work was supported by the USSSP and NSF

Correspondence and requests for data should be addressed to J.C.Z. (e-mail: jzachos@earthsci.ucsc.edu). 